\title{
Effective Reward System and the Motivational Level of Security Employees. ( A Survey of Some Selected Federal Security Institutions in Enugu State
}

\author{
Achilike .I. Nicholas Ph.D ${ }^{1} \quad$ Akuwudike. C.Hilary ${ }^{2}$ \\ 1.Department Of Accountancy/Business Administration/Banking and Finance. Federal University, Ndufu-Alike, \\ Ikwo. Ebonyi State, Nigeria \\ 2.Department of Business Administration, Eastern Palm University, Ogboko Ideato South, Imo State, Nigeria
}

\begin{abstract}
In recent times now, Nigeria has been experiencing an unprecedented security challenges virtually all over the states in the country, especially the North East where Boko Haram Islamist group having been laying siege and the Middle Belt region where the Fulani herdsmen have been killing and taken over of lands. Government and military authorities having been deploying troops and other military strategies' are being adopted to tame this ugly menace and to reduce this ugly situation of wanton destructions of life's and properties by these marauders. This study was conducted to assess the effect of reward system on the motivational level of these security personnel's deployed to fight this menace and how satisfaction with rewards can reduce the security challenges bedeviling this country. This study was conducted using some selected security employees from Federal security institutions in Enugu State. 202 respondents were selected from the aforementioned security institutions in the State. The design of the study was descriptive statistics. Data collected for this study were analyzed using mean, standard deviation, percentage method with frequencies to test the three research questions namely: what are the effects of employee's motivation on national security? What are the factors that increase motivation of security employees? What is the relationship between employee rewards and organizational performance?. The result obtained from the analysis showed among others that reward and motivation of security employees have significant effect on national security, that not only it gives the security personnel a sense of belonging, it encourages high level of performance even if it means paying the ultimate price. Going by the findings of this study, it can be easily inferred that security men reward package matters a lot and should be a concern of both the military authority and the Nigerian government. The results obtained from the research questions showed that security employees place great value on the different rewards given to them by their military authority. It concludes that when these rewards are not given, security personnel tend to express their displeasure through poor performance and noncommitment to their job. It is therefore imperative for the military authority to consider the needs and feelings of its security men deployed to fight insurgents and not just overlook them in order to safeguard national security and harmony, because "a happy worker they say is a productive worker".
\end{abstract}

Keywords: Reward system, motivation, security personnel.

DOI: $10.7176 / \mathrm{EJBM} / 11-26-12$

Publication date:September $30^{\text {th }} 2019$

\section{INTRODUCTION}

Introduction.

Reward System is a vital aspect of any organization. It can actively engage and renew the overall sense of community and mission of an organization. A properly administered system of rewards can provide incentive for quality workmanship and staff performance. Likewise, a poorly administered reward system can lead to low morale, unproductive performance, and even lead to a low percentage of staff turnover. A reward system is successful when the staff interprets its policies as even handed, consistent, and relevant. Rewarding and recognizing employees is a ticklish business. It can motivate people to explore more effective ways to do their jobs or utterly discourage such efforts, (Tella, Ayeni\&Popoola, 2007).

For any organization to experience effective functioning and quality performance, it should have an in-depth understanding of its employee's needs that should inform the organization's appropriate reward systems. Hafiza etal (2011) argued that due to the fact that organizations have to perform optimally and compete effectively, they must maximize on the resources they have. One of which is the human asset, this is the most important asset any organization can possess. In order to achieve the required performance standards from the human resource, employee motivation is necessary. Employees will peg their performance to the feeling of trust that their efforts will be rewarded by the authority. According to Armstrong (2012) reward management is the means of getting better results by understanding and managing employees within an agreed framework of planned goals, standards and competency requirements. However, a desired goal and target may only be achieved effectively if the workforce gets a sense of mutual gain from the organization with the achievement of a defined performance target. It's against this background that an organization must strategically set to evaluate the effect of reward system on 
the motivational level of employee's productivity at all levels and reward them effectively.

This could be likely why Herman (2009) remarked that an effective reward system is one that seeks to meet the employees' specific needs. However, for an employee who has already achieved his/her basic needs through monetary reward, then he/she will tend to value rewards that reinforce his or her self-actualization and hence will be more motivated by relational rewards. Also, in various organizations staffs have shown that they have diverse needs that require a comprehensive total reward system to meet. As a result, the management has been faced with the challenge of implementing and offering competitive rewards to the workforce for the purpose of enhancing performance. According to Shaw (2006), Human resource managers must try to develop human resource programs that improve productivity and enhance organizational effectiveness. One popular approach to enhancing productivity has been linking rewards to performance through various forms of incentive pay such as special recognition to acknowledge outstanding individual or team achievements with small cash awards, individual performance rewards based on specific employee performance criteria and stock ownership rewards to professionals who meet specific goals. Therefore, the objective of the work is to investigate the effect of reward system on the motivational level of employees: A survey of some selected manufacturing company in Enugu Metropolis.

\section{Background of the Study}

Reward systems according to Sziligyi (2003) are outcomes or events in the organization that satisfy work related needs. Rewards systems are much more than just bonus plans and stock options but while they often include intrinsic incentives, they also include extrinsic types like promotions, non- monetary bonuses, vacation holidays or simple "thank you" from the authority. Since high morale and productivity go hand in hand, it is imperative on managers to reward employees when they hit organizational targets and stretched standards set by the organization. A properly administered system of rewards has the capacity not only to improve incentives for quality workmanship and staff performance but also strategically attract skilled employees to join the organization. The reverse may lead to unproductive performance and protest etc.

Nigeria in recent times has witnessed an unprecedented level of insecurity. This has made national security threat to be a major issue for the government and has prompted huge allocation of the national budget to security. In order to ameliorate the incidence of crime, the federal government has embarked on criminalization of terrorism by passing the Anti-Terrorism Act in 2011, fundamental surveillance as well as investigation of criminal related offences, heightening of physical security measures around the country aimed at deterring or disrupting potential attacks, strengthening of security agencies through the provision of security facilities and the development and broadcast of security tips in mass media. Despite these efforts, the level of insecurity in the country is still high. In addition, Nigeria has consistently ranked low in the Global Peace Index (GPI, 2012), signifying a worsened state of insecurity in the country. With the lingering security challenges and the inability of the security apparatus of the government to guarantee safety and security in the country, the question that borders everyone in Nigeria today is "can there be security?" Is security of lives and properties achievable?. Many schools of thought have attributed this despicable situation to lack of proper and adequate reward and motivation of security employees entrusted with this responsibilities. Whiteley (2002) describes that all people are concerned with motivation to some extent and one thing that all employees have in common is the fact that higher motivation increase performance. However, to get security employees to outperform during all conditions is one of the most difficult challenges authorities are facing (Nohria, Groysberg\& Lee, 2008). Bruzelius and Skärvad (2004) argue that to get employees motivated to work more efficiently and to support the organization's values and goals, they need to get compensated through rewards. The reward structure should encourage employees to stay within the organization as well as increase the motivation and commitment to the organization and therefore increase the productivity. (Brickley et al, 2002)

As of today, it is widely recognized that employees' motivation level and engagement depend on the perceived feeling of being fairly rewarded for one's skills, knowledge and contribution. Rewards are a key factor when it comes to creating motivation and excitement for the employees. However employees' productivity and performance in an organization determines how they will be rewarded. All these issues call for research efforts. This work is a research on how an appropriate reward package can gear up or influence security employees to develop positive attitude towards their job and the ability to rise to these challenges posed by these security threats with expediency and expertise.

\section{Objectives of the Study}

1. To verify the effects of employee's motivation on national security

2. To determine the factors that increases motivation of security employee.

3. To ascertain the relationship between employee rewards and organizational performance. 


\section{Research Questions}

1. What are the effects of employee's motivation on national security?

2. What are the factors that increase motivation of security employees?

3. What is the relationship between employee rewards and organizational performance

\section{Statement of the Hypotheses}

Ho1: Security employee motivation does not have significant effect on national security.

Ho2: There is no significant factor that affects motivation of security employees.

Ho3: There is no relationship between employee's rewards and organizational effectiveness.

\section{Conceptual Framework \\ Reward/ Reward System}

A reward is a thing given in recognition of service, effort, or achievements. It is also something given or received in return for a deed or service rendered. Technically, it is a management tool that hopefully contributes to firms' performance by influencing individual or group behavior (Karami, 2009). All businesses use pay, promotion, bonuses or other types of rewards to motivate and encourage high level performances of employees (Reena et al, 2009). Then, a reward system is a planned and structured approach to reward one or more persons who act in a desirable way. A basic rewards system in an organization is the compensation and benefits programs it offers to employees. The point is to reward employees with financial remuneration to garner loyalty, consistency, quality and value in their work. Parents also commonly use reward systems with their Children to motivate complaint behavior. A parent may give children stickers and prizes for doing chores. In the same way, every organization needs a strategic reward system for employees that addresses compensation, benefits, recognition and appreciation Generally, the reward system is accompanied by several actions both from the viewpoint of the organization and the individual. It is led to tensions for the organization. First under similar conditions people intend to refer to the institutions which provide the highest rewards. Thus organization can attract employees who have competency and qualification by offering rewards. Second, the reward that is given to employees in lieu of service compensation is a tool for receiving feedback from previous performance and third, rewards can be used as a motivational tool to improve future performance.

Hence, it seems that the reward system should be effective and efficient so that such actions are realized in the organization and this system should be designed in a way that creates maximum return both for the organization and the personnel (Karami, 2008). Paying attention to the principal needs of the individual and enjoying fair reward distribution inside and outside of the organization are among the major principles in any reward system (Laler et al., 2005). The reward system is basic to human resource management performance and compensation management since its basic task is to design and execute employees' wage and benefit systems (Bernardin \& Russell, 2003).

\section{Types of Employee Rewards Extrinsic Rewards}

In his study Tsai (2005) concluded that extrinsic rewards including monetary rewards or cash rewards are used to cater the expectations of individual employees in order keep them motivated. The author also used the notion of 'pay for performance' and identified it as most effective incentive technique to maximize the productivity of employees; however, the study concluded that the impact of pay for performance notion is short term. Danish and Usman,(2010) argued that effectiveness of a reward system is reflected by the fact that it adequately recognizes high performers in the organization and promotes and facilitates employees to maximize their productivity as well as overall performance. By reward system an organization ensures that the employees have perception that they are valuable for the company and the management acknowledges the role they play in the progress of the company. This way the morale of the workforce is boosted. When the morale of the work force is high it tends to increase its productivity both at individual level and at organizational level. In summary the study concluded that reward system can play an effective role to maximize productivity of employees and has a critical role in maintaining high level of motivation among employees. Yousaf and associates (2012) conducted a study focusing on rewards with intrinsic nature, the study concluded that workers at individual level constantly participate in social exchanges and related processes and provide their own input in developing the perception about reward system. Every employee compares the reward he/she receives against the performance delivered by him/her within the context of needs and expectations and shows and expresses satisfaction towards reward system.

Using the expectancy theory, Mendonca, (2002) opined that reward and compensation system should be based in the principle that employees have higher motivation to maximize performance if they perceive that existing rewards system is linked with performance and productivity.

\section{Intrinsic Rewards}

Torrington and associates (2009) used a different term for non-cash rewards i.e. non material rewards and 
concluded non-cash rewards tend to increase the hob satisfaction in employees particularly employees that show high productivity as compared to other employees. The researchers used two categories of nature rewards in reward systems which are extrinsic and intrinsic rewards. The extrinsic rewards are typically related to financial rewards, although they may also include formal public recognition in the form of appreciation letters, increasing benefits of employees, incentive based payments such as duty and deployment allowances The intrinsic nature rewards are generally non-financial or non-cash rewards which in the military include: recognition of success, redeployment from war zones after serving the mandatory three years, equipping the security personnel with modern equipment, treating fallen security personnel ho have paid the ultimate price as heroes etc. The study also emphasized in balancing extrinsic and intrinsic rewards to enable the reward system to adequately meet motivation needs of employees and ultimately leads to optimization of commitment, motivation, and job satisfaction of employees. These factors when optimized lead to maximization of employee performance and ultimately organizational performance is maximized (Khan, et al., 2013).

The study conducted by Serwar and Abugre, (2013) showed that there is positive relationship between the rewards and job satisfaction in employees of service industry. They concluded that the positive relationship can be used by authorities to maximise job satisfaction among employees through provision of adequate rewards. Increased job satisfaction motivates employees to strive to increase productivity with high level of efficiency and effectiveness.

\section{The concept of Motivation}

The term motivation for the first time came from the Latin term move that means movement. Motivation is referred to the reason for a particular behavior. In other words, a person does not perform any behavior for which there is no motivation or need as a stimulant. Human's motivation such as conscious or unconscious is arising from his/her needs. Therefore, in defining motivation it can be said that motivation or need is an internal state and a shortage or deprivation that obliges the person to perform a series of activities (Seyyed Javadin, 2008, p 455). Another definition of motivation is as below: "intention towards abundant attempt to provide purposes of the corporation so that such attempt is prompted to satisfy some individual needs" (Robins, 2009, p 326). It is also a theoretical construct used to explain behavior. It represents the reasons for people's actions, desires, and needs.

Providing employee motivation at a high level of performance is one of the primary tasks of managers and authorities. It means that the manager should ensure that people are working; they go to work regularly and have a positive portion of the organization's mission. Job performance is related to ability, environment as well as motivation (Mohammad zade \& Mehruzhan 2007).

Motivation is a chain process that begins with need or shortage and deprivation, then it is led to demand and causes tension and action towards a purpose that behavior of gaining the purpose is its result. Sequence of this process might be led to satisfaction of needs. Therefore, motivations encourage and stimulate the individual to perform a task or behavior. While motivation reflects a general demand, punishment and encouragement are still regarded as very strong motivations in all motivation studies. In this regard, money is considered as a tool to grant reward but it is not the only motivational factor (Seyyed Javadin, 2008, p 456).

\section{Effect of Employee Performance and Motivation}

According to authors Kulchmanov and Kaliannan (2014) the most influential factor in employee performance is the motivation of employees. Further highlighting the previous statement and claim, Raza (2012) opines that if an employee is motivated to perform better he/she find ways to improve performance and vice versa. The performance of employees can be maximized by creating a perception among them that that their hard work and effort is valuable for the company and management recognize and reward high performers. However, according to Nielsen (2013), there are also other factors to maximize performance for example by providing training and improving skills of the employees. Technological innovation and improving working conditions can also improve performance. Overall an institution may very well decide to simply lay off low performers and recruit high performers. However, it has been noticed that low level of job security and excessive pressure or pushing employees to perform better leads to employee burn out and high staff turnover. Thus authorities must find ways to improve performance while retaining employees. This can be possible by keeping them motivated to performance better. These way institutions can not only prevent employee burnout, absenteeism, protest and barricading of roads but also can maximize performance (Shields, et al., 2015).

One of the most effective factors that motivate employees is to reward them for their high performance and provide adequate incentive to further improve performance. Employees expect that the management is going to reward them if they improve their performance and if management meets their expectations then they are satisfied with their job and the institution. High level of employee satisfaction leads to high level of employee motivation. However, if the authority fails to provide adequate rewards, employee's dissatisfaction increases and high level of employee dissatisfaction leads to high level of demotivation (Danish and Usman, 2010). 


\section{Factors that increases Motivation of Employees in an Organization}

Money is the fundamental inducement; no other incentive or motivational technique comes even close to it with respect to its influential value (Sara et al, 2004). It has the supremacy to magnetize, maintain and motivate individuals towards higher performance (Houran, 2010). Frederick Taylor and his scientific management associate described money as the most fundamental factor in motivating employees to attain greater productivity (Adeyinka et al, 2007). Research has suggested that reward now cause satisfaction of the employee which directly influences performance of the employee (Kalimullah et al 2010). Rewards are a management tool that hopefully contributes to firms' performance by influencing individual or group behavior. All businesses use pay, promotion, bonuses or other types of rewards to motivate and encourage high level performances of employees (Reena et al, 2009). To use salaries as a motivator effectively, authorities must consider salary structures which should include: payment according to performance, personal or special allowances, fringe benefits, pensions and so on (Adeyinka et al, (2007).

\section{Theoretical Review}

Expectancy theory refers to a set of decision theories of work of motivation and performance (Vroom, 1964; in Ferris, 2007). Perception plays a central role in expectancy theory because it emphasizes cognitive ability to anticipate likely consequences of behavior (Kinicki et al., 2003). As said by Vroom (1964; in Kopfi, 2008), the expectancy theory has two major assumptions. The first assumption is that individual persons have perception about the consequences that result from their behavioral actions, and the causal relationship among those outcomes. These perceptions, or beliefs, are referred to as either expectancies or instrumentalities. The second assumption is that individual person has effective reactions to certain outcomes. Affective reactions reflect the Valence (positive or negative value individual place or results) of outcomes (Kinicki et al., 2003). According to the expectancy theory, individual will be motivated to perform by two expectancies (Ferris, 2007; Isaac et al., 2001). Expectance is the probability that the effort put forth will lead to the desired performance. The second expectancy (also referred to as instrumentality) is the probability that a particular performance will lead to certain preferred outcomes. When the probability of some effort will not be rewarded, the employee will not be highly motivated to perform a certain task. Expectancy theory primarily relies upon motivators to clarify causes for behaviors exhibited at work (Leonard, Beauvais and Scholl, 1999). External rewards are viewed as inducing motivational states that fuels behaviors, as opposed to intrinsic motivators, when behaviors are derived from internal forces such as the enjoyment of the work itself because it is challenging, interesting and so on (Isaac et al, 2011).

On the other hand, in Goal setting theory, Locke, Shaw, Sarri and Latham (2008) defined a goal as what an individual attempts to accomplish; it is the object or aim at certain actions. The basic assumption of goal-setting is that goals are immediate regulators of human actions (Locke et al., 2008). Evidence from the goal setting research indicates that specific goals leads to increase performance and that difficult goals, when individuals have accepted them, results in higher performance than easy goals (Locke 1968 in Austin and Bobko, 1985; in Locke, 2004). Goal setting has four motivational mechanisms (Bryan and Locke, 1967; Locke and Latham, 2002). The first motivational mechanism is that goals that are personally meaningful and interesting tend to focus an individual's attention on what is important and what is relevant (Locke et al., 2008). The second mechanism is that goals have an energizing function. Simply puts, higher goals leads to more effort than lower goals (Bryan and Locke, 1967). The third mechanism is that goals affect persistence. Persistence is the effort expended on a specific task over a certain amount of time (Laporte and Nath, 1996). Normally, the more difficult a goal is to achieve, the higher the persistence. The last motivational mechanism holds that goals affects action indirectly by leading to the arousal, discovery and use of knowledge and strategies (Wood and Locke, 1990 in Locke et al., 2002). Regarding the impact of goal setting on intrinsic motivations, Elliot and Harackiewiez (1994) show some interesting evidence in their article. They explain, by means of regression analysis that the effect of performance or mastery focused goals on intrinsic motivation depends on the degree of achievement orientation of an individuals. Goals are simultaneously and object or outcome to look for and a standard for satisfaction (Locke et al., 2002). When an individual wants to achieve certain goals it means that this individual will not be satisfied until he reaches that goal. Therefore, goals serve as the inflection point or reference standard to satisfaction versus dissatisfaction (Mento, Locke and Klien, 2002). (Locke et al, 2002) add to this that individuals that produce the most, those with difficult goals, are harder to satisfy. In this case, individuals that set high goals produce more as they are dissatisfied with less. 
Research Question 1: What are the effects of security employee's motivation on national security Mean Rating of the Effect/Impact of security employee's motivation on national security

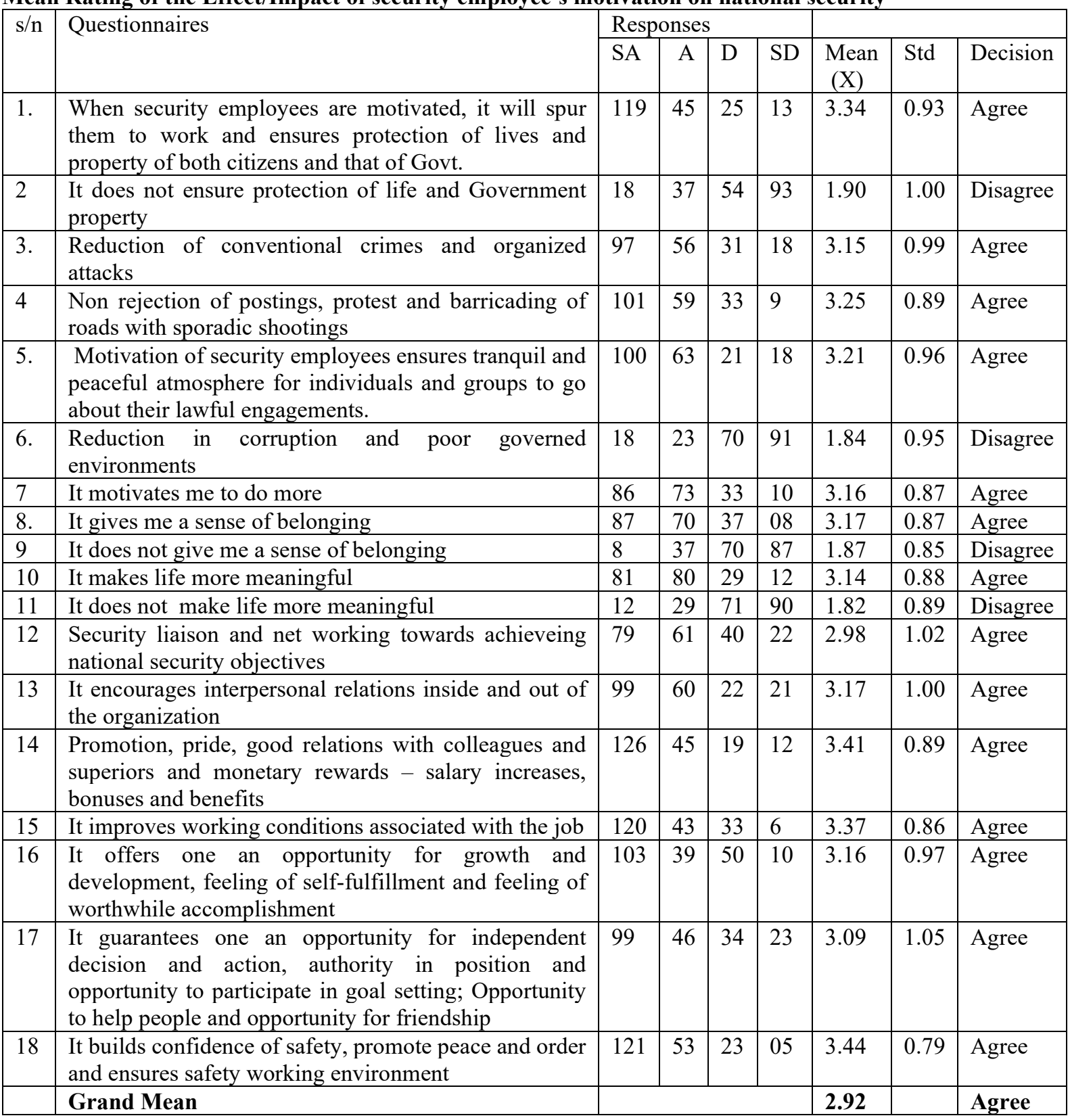

\section{Source: Field Research 2019}

The table above showed that of the 18 items on the effects of security employee's motivation on national security in areas under study, the respondents agreed with 14 items $(1,3,4,5,7,8,10,12,13,14,15,16,17$ and 18) as they recorded mean scores that are above the cut off mark of 2.50 . They however disagreed with 4 of the items $(2,5,9$, and 11). The standard deviation for all the items are small signifying that there is homogeneity in the responses of the respondents. From the foregoing, the answers to research question one is that when security employees are rewarded and motivated, it will spur them to work and ensures protection of lives and property of both citizens and that of Government, there will be high reduction of conventional crimes and organized attacks, there will be non rejection of postings, protests and barricading of roads with sporadic shootings, it will ensure tranquil and peaceful atmosphere for individuals and groups to go about their lawful duties and engagements. It gives them sense of belongings etc. 
Research Question 2: What are the factors that increase motivation of security employees? Mean Rating of the factors that increase motivation of security employees

\begin{tabular}{|c|c|c|c|c|c|c|c|c|}
\hline \multirow[t]{2}{*}{$\mathrm{s} / \mathrm{n}$} & \multirow[t]{2}{*}{ Questionnaires } & \multicolumn{4}{|c|}{ Responses } & \multirow[b]{2}{*}{$\begin{array}{l}\text { Mean } \\
(\mathrm{X})\end{array}$} & \multirow[b]{2}{*}{ Std } & \multirow[b]{2}{*}{ Decision } \\
\hline & & SA & A & $\mathrm{D}$ & $\mathrm{SD}$ & & & \\
\hline 19 & $\begin{array}{l}\text { Good incentives, good conditions of service and social } \\
\text { security }\end{array}$ & 122 & 36 & 31 & 13 & 3.32 & 0.96 & Agree \\
\hline 20 & $\begin{array}{l}\text { Good incentives, good conditions of service and } \\
\text { social security do not motivates security employees. }\end{array}$ & 13 & 37 & 36 & 116 & 1.74 & 0.98 & Disagree \\
\hline 21 & Provision of adequate weaponry and training & 98 & 63 & 27 & 14 & 3.21 & 0.93 & Agree \\
\hline 22 & $\begin{array}{l}\text { Provision of adequate weaponry and training do not } \\
\text { motivate security employees. }\end{array}$ & 14 & 27 & 72 & 89 & 1.83 & 0.91 & Disagree \\
\hline 23 & Prompt Payment of duty and hazard allowances & 99 & 52 & 28 & 23 & 3.12 & 1.04 & Agree \\
\hline 24 & Redeployment of security personnel from time to time. & 88 & 61 & 31 & 22 & 3.06 & 1.01 & Agree \\
\hline 25 & $\begin{array}{l}\text { Good working conditions, fringe benefits, promotion } \\
\text { and security }\end{array}$ & 99 & 60 & 22 & 21 & 3.17 & 1.00 & Agree \\
\hline 26 & $\begin{array}{l}\text { Immediate settlement and payments of entitlements of } \\
\text { deceased security employee benefits to his or her } \\
\text { family. }\end{array}$ & 120 & 43 & 33 & 6 & 3.37 & 0.86 & Agree \\
\hline 27 & $\begin{array}{l}\text { Military and Government authorities taken care of } \\
\text { family members of soldiers who have paid the ultimate } \\
\text { price in active service. }\end{array}$ & 103 & 39 & 50 & 10 & 3.16 & 0.97 & Agree \\
\hline 28 & $\begin{array}{l}\text { Modernaization of security agencies with training, } \\
\text { intelligence sharing, advanced technology, logistics, } \\
\text { motivation and change of orientation. }\end{array}$ & 99 & 37 & 43 & 23 & 3.05 & 1.08 & Agree \\
\hline & Grand Mean & & & & & 2.90 & & Agree \\
\hline
\end{tabular}

\section{Source: Field Research 2019.}

The table above showed that of the 10 items on the factors that increases motivation of security employees in areas under study, the respondents agreed with 8 items $(19,21,23,24,25,26,27$ and 28) as they recorded mean scores that are above the cut off mark of 2.50. They however disagreed with 2 of the items (20 and 22). The standard deviation for all the items are small signifying that there is homogeneity in the responses of the respondents. From the foregoing, the answers to research question two on the factors that increases motivation of security employees are as follows: good incentives, good condition of service and social security: provision of adequate weaponry and training. Prompt payment of duty and hazard allowances, redeployment of security personnel from time to time etc. According to the respondents all these are necessary factors that will motivate security personnel to fight insurgents without looking back.

Research Question 3: What is the relationship between employee rewards and organizational performance? Mean Rating of the relationship between employee rewards and organizational performance .

\begin{tabular}{|c|c|c|c|c|c|c|c|c|}
\hline \multirow[t]{2}{*}{$\mathrm{s} / \mathrm{n}$} & \multirow[t]{2}{*}{ Questionnaires } & \multicolumn{4}{|c|}{ Responses } & \multirow[b]{2}{*}{$\begin{array}{l}\text { Mean } \\
(\mathrm{X})\end{array}$} & \multirow[b]{2}{*}{ Std } & \multirow[b]{2}{*}{ Decision } \\
\hline & & SA & A & $\mathrm{D}$ & SD & & & \\
\hline 29 & $\begin{array}{l}\text { Bases decisions and rewards on formulated } \\
\text { organizational policies }\end{array}$ & 117 & 52 & 21 & 12 & 3.36 & 0.89 & Agree \\
\hline 30 & $\begin{array}{l}\text { Does not base decisions and rewards on formulated } \\
\text { organizational policies }\end{array}$ & 14 & 37 & 58 & 93 & 1.86 & 0.95 & Disagree \\
\hline 31 & $\begin{array}{l}\text { Good working conditions, fringe benefits, promotion } \\
\text { and security leads to high organizational performance }\end{array}$ & 99 & 60 & 22 & 21 & 3.17 & & Agree \\
\hline & Grand Mean & & & & & 2.80 & & Agree \\
\hline
\end{tabular}

Source: Field Research 2019.

The above tavble showed that of the 3 items on the relationship between employee rewards and organizational performance in areas under study, the respondents agreed with 2 items (29, and 31$)$ as they recorded mean scores that are above the cut off mark of 2.50. They however disagreed with 1 of the items (30). The standard deviation for all the items are small signifying that there is homogeneity in the responses of the respondents. From the foregoing, the answers to research question on the relationship between employee rewards on the organizational performance in the areas under study is that it bases decisions and rewards on formulated organizational policies and that good working conditions, fringe benefits, promotion and security leads to high organizational performance. 


\section{Findings}

1. Employee reward and motivation have significant positive effects on national security. The results indicate that when security men are well rewarded and motivated, it will spur them to work assiduously and ensures protection of lives and property of both citizens and the government.

2. Equally, rewards and motivation leads to reduction of conventional crimes and organized attacks, thereby building confidence of safety, promotion of peace and order and ensuring safety working environment.

3. Good incentives, good condition of service and social security among others are the foremost factors that motivates security employees.

4. There is a significant relationship between employee's rewards and organizational effectiveness in areas under study.

\section{Conclusion}

This study has revealed that reward and motivation of security employees deployed to maintain security have significant positive effects on national security. It is a well-known fact that human performance and attitude of any sort is improved not only by increase in remuneration, but equally improved by provision of good incentives, good condition of services and social security. Going by the findings of this study, it can be easily inferred that employees reward package matters a lot and should be a concern of both the government and security authorities. This is because when these rewards are not given, security personnel's tend to express their displeasure through poor performance and non-commitment to their job and refusal to carry out official instructions. It is therefore imperative for the security and military authorities to consider the needs and feelings of its security men deployed to carry out military operations and not just overlook them in order to safeguard national security and harmony, because "a happy worker they say is a productive worker".

\section{Recommendations}

On the basis of the implication of the study the following recommendations were made;

1. The government and military authorities should as a matter of national policy treat the welfare and packages of military personnel's, including their feelings and needs with all seriousness in other to safeguard national security and harmony.

2. There should be modernization of security agencies with training, intelligence sharing, advanced technology, logistics and change of orientation of our security men.

3. There should be adequate provision of weaponry and other military equipments to fight insurgents. A situation whereby these insurgents have superior weapons more that the Nigeria military is an insult on Nigerian security system.

4. The military authority should from time to time redeploy soldiers who have served three years in a particular operation to another location. Again, settlement and payments of entitlements to the families of soldiers who died in active service should not be toyed with by those concerned. There should be prompt and immediate payments of their entitlements to their families.

\section{References}

Armstrong, M. (2012).Armstrong's Handbook of Human Resource Management Practice, 12th Ed. London Philadelphia New Delhi.

Assam, A.P. 2002. Motivation and Job Satisfaction. Unpublished M.Sc Dissertation University of Lagos, Nigeria. Bergum, B \& J. Lehr. 2004. "Monetary Incentives and Vigilance." Journal of Experimental Psychology, vol. 7(3) Bhattacharya, S.,\& Mukherjee, P. (2009) Rewards as a Key to Employee Engagement: A Comparative Study on I.T. Professionals. ASBM Journal of Management, Vol,2(1)

Brickley, J. A., Smith, C. W., Zimmerman, J. L., \& Willett, J. (2002) Designing Organizations to Create Value, McGraw-Hill Companies, New York

Bussin, M. (2011). The Remuneration Handbook for Africa. Randburg: Knowres Publishing.

Chiang, F.F.T., \& Birtch, T.A. (2007).The Transferability of Management Practices: Examining Cross-national differences in Reward Preferences. Human Relations Journal Vol, 6 (9)

Daniel.C \& Caryl ,n(1995). "Exchange Variables as Predictors of Job Commitment and Turnover. The Impact of Rewards Cost Alternation and Investments" Journal of Organizational Behavior and Human Performance Journal, Vol.27(4).

Egwuridi, P.C. 2001. Job Satisfaction: Effects on Job Characteristics. Unpublished MSc Dissertation University of Lagos, Nigeria.

Giancola, F. (2008). Should generation profiles influence rewards strategy? Employee Relations Law Journal, Vol. 34(1)

Grobler, P.A., Wärnich, S., Carrell, M.R., Elbert, N.F., \& Hatfield, R.D. (2011). Human Resource Management in South Africa.(4th edn.). Andover: Cengage Learning. 
Hafiza, N., (2011). Relationship between Rewards and Employee Motivation in the Non-Profit Organization of Pakistan.Business Intelligence Journal, Vol.4(2).

Herman, A. (2009). Performance Management. 2nd Ed. Pearson International Edition.

Karami, B. (2009). Studying the effects of financial rewards on increasing of production per capita in Isfahan Steel Company (Master's thesis, Department of Management and Economy, University of Isfahan)

Mujtaba, B.G .and Shuaib , S .(2010), "An Equitable Total Rewards Approach to Pay for Performance Management”. Journal of Management Policy and Practice, Vol. 11(4).

Nwachukwu, C. C.(2004).'Effective Leadership and Productivity. Evidence from a National Survey of Industrial Organization". African Journal for the study of Social issues, Vol.1(2)

Pink, D. H. (2011) Drive: The surprising Truth About What Motivates Us, First Riverhead Trade Paperback Edition, New York, N.Y., U.S., Penguin Group Inc

Shaw, F. (2006).Human Resource Management, 6th Ed. Houghton Mifflin Company Boston New York.

Whiteley, P. (2002) Motivation, Chichester, U.K., Capstone Publishing 